the Mohammedan rebellion, will, no doubt, take the route of Haiphong, as it is shorter than that of Pakhoi, and has practicable water-communication throughout its whole length.

THE latest news from Dr. Gerhard Rohlfs informs us that he is at Tripoli, under the protection of the French consul. He was to proceed to Wadai on December 15 , and was daily expecting rich presents from the Emperor of Germany, which he was instructed to offer to the new sultan of this remote kingdom.

DR. Crevaux, the explorer of French Guiana, has reached the source of the Oyapol, and crossed the range which separates Oyapok from the Amazon basin.

L'Exploration, of December 7, contains several interesting letters from $M$. Soleillet, who, it will be remembered, started some months ago from the French West African settlements for exploration of the African interior. $H$ is last letter is dated from Kouniakary, the capital of Segou, from which he hopes to reach Timbuctoo.

Accompanying an article on the Bolan Pass in the December number of the Giographical Magazine is a map of the Bolan, the Mula, and other Passes, by Mr. Trelawny Saunders, an admirable specimen of accurate and carefully executed cartography.

ARE THE FOSSTL FLORAS OF THE ARCTIC REGIONS EOCENE OR MIOCENE? AND ON THE CAUSES WHICH ENABLED THEM TO EXIST IN HIGH LATITUDES

7 HE question of the conditions and their origin under which floras, presumably requiring a temperate climate, were enabled to exist in Polar regions has been so frequently discussed both before and since the recent Arctic Expedition, that it is strange to find any aspect of the subject having remained unnoticed.

There are some points, however, which can be by no means regarded as conclusively settled, and upon these I wish to say a few words. In the first place the age of the so-called miocene floras has, I believe, been wrongly interpreted. Again, the temperatures required by then may have been over-estimated. Lastly, there seems to me to be no occasion whatever to invoke astronomical causes or to invent recurring periods of heat and cold, of which we have no geological proof, in order to account for their former presence there.

In the first place, then, if re examine the palaontological evidence, the only kind on which the age of the rociss has been decided, we find that it is very far from conclusive, and instead of pointing to a common miocene arse for all the tertiary beds in the Arctic regions, we find that there are many reasons for believing some of them at least to be eocene. The piant eridence is, indeed, in the present state of our knowledge, almost negative; but what similarity there is in the floras to those of the miocene is directly against their being of that age instead of in favour of it, for no two floras which are much alike and met with in widely separated laritudes can possibly have been contemporaneous, although floras of quite disiinct facies may have bcen so. The fact that a proportion of the plants have been identified by Heer with those of the miocene of Switzerland is of no weight whatever, as a considerable proportion are equally identified with the undoubted eocene lower lignitic of America, and a number of forms in the latter again with the miocene of Switzerland. The truth is, that at present any formation containing dicotyledons may be, with almost equal plausibility, referred to either eocene or miocene to suit the author's requirements ; for besides the similarity in the ovate and lanceolate leaves from botb, many species actually range right through them. Were the age of the Alum Bay and Bournemouth beds

$x$ This was written before attention was called to Saporta's address at the anniversary meeting of the Royal Scciety. not thoroughly established, from their fossil leaves, even they would certainly have been referred to miocene. This will not, I am happy to think, always be the case, for there are a great number of plant forms which appear to be decidedly typical of, and confined to, each stage respectively. Already a number of hitherto supposed miocene deposits in Europe have been recognised as eocene, and as soon as those forms which from their range are of negative value, have been set aside, the confusion will cease. I have, indeed, strong hopes that we may be able to recognise each stage in the eocene of temperate latitudes by its plants, more from the incorning of new and distinct types, however, than the continued presence of older forms.

The confused way in which floras of many ages have been mixed together, seems to me to have arisen in a very simple manner. The flora of Oeningen must undoubtedly be accepted as a typical miocene flora, and contains but very few eocene forms-if indeed any. It contains, however, many plants common to other isolated fragments of strata which contain mixed floras, that is, floras with percentages of eocene as well as miocene plants. There being no typical series from undoubted eocene available as standards of comparison, the plants common to the miocene have alone been taken to determine the age of these beds, and the unknown eocene forms have thus been enrolled as miocene, and in their turn used to identify other still more distinctly eocene beds as miocene; much in the same way that the Barton beds were formerly identified, from their possessing a few species in common, as London clay, and the species peculiar to the Barton horizon, subsequently made use of to identify calcaire-grossier and Bracklesham beds in their turn with the London clay.

The oldest Arctic flora containing dicotyledons, and which, therefore, has any bearing on the subject, is that of Kome in North Greenland. It is mainly composed of ferns and gymnosperms, and its age may probably have been correctly inferred. The next beds, referred to the upper cretaceous, appear to be approximately of the same age as the Dakota beds, and therefore, in my opinion, decidedly supra-cretaceous relative to that formation in Europe.

We have next, if Heer's nomenclature is right, an immense gap right from the cretaceous to the miocene, to which latter he has referred all the rest of the obviously newer beds. He does not account in any way for the absence of eocene deposits, and relies exclusively on plant evidence, which I think should be, for the present, absolutely set aside. Before quitting the subject of the plants, I wish it to be understood that $I$ in no way intend to disparage Heer's judgment. Considering the nature and condition of the specimens submitted to him, it is a marvel that he could have drawn and desaribed them in so admirable a manner. But Heer has unfortunately never bad a large series of definitely eocene plants to describe, and hence almost all his floras are cretaceous or miocene. I profoundly respect his work, and only to strengthen iny plea that leaf evidence may be temporarily set aside or reconsidered, I mention that already three floras pronounced by Heer to be miocene, have since proved one cretaceous and two eocene; and still others must follow.

Assuming that I may be allowed for the present to dismiss the plants, I will touch upon the purely physical evidence, which seems to me to be, small as it is, entirely in favour of the eocene age of the beds. In the first place we have the great probability that eocene remains would, if they had ever existed, be found in their proper sequence, considering the number of widely-separated places in the North Polar area from which plant-remains have been obtained. It is certain that they must have existed, since the area continued land throughout eocene times, for there are no marine deposits of that age; and there is 
abundant evidence of more than one kind that Europe and America were connected then, and that animals and plants passed between them. Besides that, the floras themselves contain both American and European types, and during the middle eocene a great number of plants were common to both coniinents.

In the next place the temperature of the eocene period in Europe was much hotter than that of the miocene, and therefore presumably more favourable to the growth of such floras in northern latitudes. To call them miocene we have to admit the former existence of a climate sufficiently uniform to have enabled the same species of plants to grow simultaneously from Italy and the United States to the 7oth parallel, a state of things not in accordance with our present experience of plant distribution. But if we assume them to be eocene, the decreasing temperature which prevailed from that time to the miocene would have gradually and naturally driven the forms southward, and thus the very similarity of the miocene floras of America and Switzerland to those of the Arctic regions, renders it most unlikely that they were of the same age, and almost certain that the latter were considerably older.

In comparing the eocene and miocene temperatures we find, as already stated, that the former most readily accounts for the growth of temperate floras in high latitudes. Taking Heer's estimate that the miocene temperature in the latitude of Switzerland at the sea-level was only $9^{\circ}$. C. warmer than at the present day, the progressive decrease of heat to the north is not so much in accordance with that of the present time, as it is found to be on the supposition that they belong to the eocene; we have to suppose that the mean temperature diminished in a less degree.

Speaking rougbly, the present decrease in the isotherm from latitude $50^{\circ}$ of south England, to that of Spitzbergen, is about $10^{\circ}$ Fahr. for every $10^{\circ}$ of latitude. This is as nearly as possible the ratio of decrease between England and Greenland in eocene times as implied by the floras, supposing them to be of one age. If, as I assume from all the data I can collect, England in middle eocene times possessed a mean annual temperature of $70^{\circ} \mathrm{F}$. Greenland would naturally have had one of $50^{\circ}$, which is that assigned to it by Heer $\left(9^{\circ} \mathrm{C}\right.$.). The decrease thence to Spitzbergen and Grinnell-land is hardly less rapid, being about $\mathrm{I}^{\circ} \mathrm{F} .\left(\mathrm{y}_{2}^{\circ} \mathrm{C}\right.$.) of cold for each degree of latisude. Heer calculates-principally on the mean temperatuie required by Platanus-that between Greenland and Spitzbergen, $8^{\circ}$ lat., it was $4^{\circ} \mathrm{C}$, but very unaccountably fancies that between Spitzbergen and Grinnell-land no further decrease took place, and upon this assumes that trees might have extended to the very Pole itself. The evidence against it, however, seems perfectly clear, for all the planes and limes, and more temperate forms have disappeared, and the genera found there, with a single exception, have representatives which at the present day live within the Arctic Circle. This exception, Taxodium, judging from its present habitat, Mexico and the Southern United States, would necessitate a climate completely different from that required by all the other plants with which it is associated. They form a distinctly Arctic assemblage: the spruce, especially, is never met with fossil to the south, except in inter-glacial beds. The fossil Taxodium must, therefore, only be looked upon as an allied extinct species, whose resemblance to living forms does not imply identity of habit, since all other consicierations are against it. A similar instance is found in the willow, which is generally characteristic of the north; yet Salix humboltiana is found in the Amazon districts and $S$. safsaf in Egypt; and similarly, although Cassia is eminently characteristic of tropical and subtropical zones, C. marylandica flourishes on the banks of the Lake of Geneva As it is essential to get rid of the evidence of Taxodium, if we are to suppose this forme: climate followed the present natural laws, I shall refer to some remarks by Lesquereux upon the nearly allied redwoods.

In describing the pliocene plants of California, he concludes that they are related to the present flora of the Atlantic slope, and not to that of California. He accounts for their destruction on the eastern side by the powerful agencies of glacial action, marine submersion, and longsustained volcanic cataclysms. When these had ceased the sheets of water between the Missouri River and the Rocky Mountains and the mountains themselves prevented the old flora from again occupying the Western area. Some of the pliocene species, however, were preserved through the glacial epoch in California, but modified, for the most part, by the cold conditions they had undergone. "The two species of Sequoia-one the more predominant, the other the more remarkable, of the flora of California-are evidently also remnants of the pliocene. S. gigantea, which in all probability covered the higher slopes of the mountains of that epoch, has been destroyed everywhere, except in some deep valleys. . . . The other, $S$. sempervirens, left here and there, has again taken the ascendency under more favourable physical circumstances. Its present distribution explains its preservation until the present epoch. According to Prof. Bolander, "the distribution of the redwood depends upon sandstone and oceanic fogs. Where either one of these conditions is wanting there is no redwood. The redwoods begin in the northern part of Monterey County, in isolated groups, in deep, moist cañons. A short distance south of Monterey City, on the Monterey Bay, a white bituminous slate sets in, and extends nearly to Pajaro River. On this no redwood is found, but Pinus insignis. At Pajaro River, eight to ten miles from the ocean, they set in again, and extend to nearly twenty-eight miles south of this city (San Francisco), either in deep cañons, or in groves extending over several ridges eastward, as far as the fog may reach. Then they continue in similar localities to latitude $42^{\circ}$, the state boundary."

The existing allied species withstood a glacial period in California; there is no improbability in supposing that older and extinct species may have habitually supported a cold temperature. It appears that they belone to a very old type, now confined to a limited area, and becoming extinct, at whose survival we cease to wonder when we reflect that individual trees have been calculated to be 3,000 years old. To pass through the life of such a species, an enormous period must be required, for only 100 generations might carry us back 300,000 years, with as little modification as an annual plant might undergo in 100 years. The sandstone soil and damp sea fogs required by them in their native habitat, may explain the difficulty in getting them to grow under cultivation except in comparatively warm latitudes-and it is upon plants under cultivation Heer's estimate in Europe is based-but lessens our surprise that they should bave existed in Greenland or farther north during the eocene time.

Apart from Taxodium, therefore, there is every evidence, in the disappearance of temperate forms and the preponderance of conifers of boreal type, that, as at the present day, there was a natural and progressive decrease of temperature to the north between Grinnell-land, Spitzbergen, and Greenland.

In the next place I would call attention to the possibility that the respective temperatures thought to be requisite for the growth of such associations of plants as are found fossil in these various lands may be in excess of the minima which would have sufficed. If this were the case, it would of course remove to a slight extent an argument $I$ have just brought forward against the miocene age of the deposits. One of the conditions peculiarly favourable to the growth of trees in northern latitudes is the protracted length of the summer days, and it is an 
ascertained fact that they require less heat in latitudes above $60^{\circ}$, owing to this rapid lengthening of the days. The chemical action of the sun's rays seems in some way to compensate for feeble warmth, and vegetation receives more impulse from the presence of the sun than from temperature in the shade. As examples of this, De Candolle ${ }^{1}$ mentions that Fagus syluatica exists in the north with a less temperature than it can support elsewhere; and that the limits of growth of barley prove the point conclusively.

It appears certain, according to De Candolle, that in very few cases has even intense cold, during natural periods of rest, any injurious influence upon plants, and that their northern limits are not determined by excess of cold but by want of heat. The destructive agents are late spring frosts, or premature heat followed by chills; and so fatal are their effects that one week in May has killed entire stocks of sub-tropical plants which had stood considerable frost in winter. There is no doubt that many plants would grow in much colder latitudes if the temperatures of each month were cyclically regular. Fraxinus excelsior, L., supports great cold, especially when accompanied by fogs, and penetrates as far north as $64^{\circ}$. Ilex aquifolizm, L., reaches latitude $62^{\circ}$ in Norway, and, like Abies, is limited in range, not by excess of cold, but want of heat. Evonymus europaus, L., is found just within $60^{\circ}$, and must occasionally suffer intense cold. But perhaps the well-known Chancerops humilis, L., affords the most striking familiarly-known instance of capricious distribution. It is indigenous to Nice in latitude $40^{\circ}$, yet it is not found anywhere in Italy, with a trifling exception, until Calabria is reached. Under cultivation it bears a very considerable amount of winter frost, the limit of which I have not ascertained, nor the minimum it encounters at Nice. I merely mention these instances as indicating possible sources of error, for were Cham ærops extinct and found fossil at Nice, we should infer from it, with every appearance of probability, that the temperature of Nice had been the same as that of Sicily or Granada, the more normal homes of the palm.

One of the most remarkable facts connected with Alpine or Arctic plants is the length of time they can endure the absence of light while they are covered with snow, and when thus protected they would be unaffected by even Arctic cold. Evergreens, as we see by the Alpine rhododendron, are equally unaffected, and I have in Switzerland seen laurels, bays, and acubas shrouded in snow for many weeks without injury. I will mention but one other instance of the extent to which trees will sometimes bear cold, quoted by Herschel." "In the valley of the black Irkut, in Siberia, Atkinson found a ravine filled with ice, and with large poplars growing in it, with their trunks imbedded $25^{\prime}$ in snow and ice, while the brancbes were in full leaf. Around each stem was a hollow of 6" thawed and full of water." Besides mere heat and cold there are many influences known and unknown which limit the range of plants. The distribution of the vine is a case in point, for it is well kown that in historic times it was extensively cultivated in England, Normandy, and parts of Prussia, in which it will no longer ripen its fruit.

While the winter temperatures in these Arctic regions, if accompanied by snow and fogs, may bave been of extreme severity, the summer temperature need not have been high, for the present Arctic and Alpine plants, including roses, species of Betula, Salix, Empetrum, Vaccinium, and conifers need but little heat.

Having attempted to show that the amount of heat really required was not so large as bas been imagined, I will endeavour to prove that it, even upon Heer's assumption, might easily have been furnished by physical causes which we know did, in all probability, exist in

De Candolle, "Géog. Botanique," vol. i., 1855. 2 Examples used by De Candulle.

3 "Physical Geography," p. $3^{12}$ eocene time, and were quite independent of astronomical causes and change in the position of the earth's axis, of which there seems to me no proof whatever, geological or otherwise. At least, to qualify this assertion, if such have existed in the past, there is no need to invoke them in this particular case. Central heat may, of course, be dismissed as having had too little influence in eocene time to be appreciable.

We may roughly estimate, on Heer's basis, that the average temperature between the latitudes and longitudes of England and Iceland was not more than from $15^{\circ} \mathrm{F}$. to $20^{\circ} \mathrm{F}$. warmer in eocene (or miocene of Heer) times than it is at present, and we may assume also on the evidence we possess that the present climate would permit any of the eocene floras, supposing they still existed, to grow in latitudes not more removed from those in which they are found than $15^{\circ}$ to $20^{\circ}$ farther south. For example, the English eocene flora could now exist in Madeira, the Iceland eocene flora in the Isle of Wight, that of Spitzbergen in Sweden, and that of Grinnell-land in NorthernNorway. We have therefore to seek for some cause adequate to produce a difference in the temperature of Greenland, for instance, equal in degree to that of $20^{\circ} \mathrm{F}$. or $20^{\circ}$ latitude as a maximum. Following upon a map the isotherms of the 7oth parallel, we see that Prince Albert Land has a temperature of but. $5^{\circ} \mathrm{F}$, whilst Lapland, in the same latitude, has one of $32^{\circ} \mathrm{F}$. There is evidently here a cause at work capable of influencing the temperature to the extent of $27^{\circ} \mathrm{F}$.; therefore a more powerful cause than is required. The same map shows us obviously that this agent is the sea. Wherever the Arctic waters find egress or penetrate the land, the isothermal lines around the Pole are deflected south. In like manner the line denoting the limits of trees is in many places pushed back more than $10^{\circ} \mathrm{S}$. by the ice-laden water flowing from the Arctic Ocean. From Lapland to Siberia it is, except for a short distance, within the Arctic circle, principally within the 7oth parallel. Nearing Behring's Straits it is sharply deflected south by the Polar Sea, but away from its influence, it as suddenly rises and again (North America) far overlaps the Arctic circle, until it once more comes under the influence of the cold seas and channels penetrating south into Hudson's Bay, which drive it to below the 6oth parallel. Avoiding Greenland, it includes part of Iceland and the whole of the North Cape, owing to the influence of the Gulf Stream. The influence of this warmer water, cold as it is here, is no less remarkable, for, by merely shutting off the Arctic currents from close proximity to the shore, it enables trees to grow on the coast, and at a point on the Arctic circle between Iceland and the Norwegian coast, raises the temperature, according to Herschel, full $20^{\circ}$ above that which is normal to the latitude.'

We thus see that the limit of trees enters the Arctic circle wherever the land has a great extension south or where the Gulf Stream raises the temperature, but that it especially shuns wherever the Arctic waters penetrate the land, even in the smallest gulfs or bays. The lands between Hudson's Bay and Davis' Straits, cut up by water, and the islands in the Arctic Ocean surrounded by water, are intensely cold and destitute of treesalmost of vegetation. The cause of Greenland's being shrouded in ice is its unknown and exceptional extension towards the Pole and the increased height of land in its northern portion. These appear to be necessary conditions of such complete glaciation as we there see, as shown by the absence of an ice-cap in Grinnell and other equally northern lands. The present condition of Greenland is wholly abnormal, and, presenting such unusual conditions, has heightened the astonishment felt when the former mildness of its climate became known.

If we were able to shut off from the Atlantic the enor- 
mous Arctic currents which chill it, we should produce at once a greater increase of heat than is required by the floras. If, further, we impinged the Gulf Stream upon its shores, without cooling it down by floating icebergs upon its back, we might be able to induce at least an even more temperate vegetation to grow there.

Water is thus seen to be the great factor in distributing heat and cold in northern regions, and not land, as has been generally taught. Humboldt believed the rigorous climate of America to be due to high land stretching to the Pole; Lyell taught that with great polar seas and an excess of land at the equator, the hottest conditions possible on the globe would be produced, and that with land at the Poles and a great equatorial sea, the coldest conditions would ensue. A study of the isothermal lines leads to the contrary belief that the presence of land at the Pole, even if ice capped as Greenland is, would be less productive of cold than a polar ocean with free exits, for air has not the distributing power possessed by ocean streams, and when these are ice-laden the effect is still greater.

It only remains to call attention to such proof as we have, that these conditions really did exist in eocene time, and that the Arctic currents were actually shut off from the Atlantic in those days by continuous land which connected the two continents of Europe and North America. In the eocenes of Europe and North America we have evidence of a great, and, comparatively speaking, sudden rise of temperature, and this was followed in due course by a mingling for the first time of the floras and faunas of the two continents. That there was land communication to the north is further evidenced by the occurrence of types of both kinds in the floras now found upon the spots on which they grew. In further support of this theory we bave the fact that no trace of sea-deposit of eocene agre has ever been found in the polar area, all the vestiges of strata remaining showing that these latitudes were then occupied by dry land.

If we may assume that these conditions really did prevail, and that all the outlets into the Atlantic were closed by the elevation of the present sea-bed between $60^{\circ}$ and $70^{\circ}$ (where, I believe, the sea is even now shallower) into land of moderate elevation; with or without prolongations south to the 5oth latitude; and the north of Greenland submerged, a temperature would ensue more than adequate to support all the plants yet found fossil in eocene or miocene Arctic beds. The result would be that the zone of greatest heat rould be far north of the equator; for while the southern hemisphere was still cooled by the Antarctic currents rising to the surface, the North Atlantic would be practically a landlocked sea, cut off from southern cold by the tropics, from northern cold by land, and heated by the sun like the Gulf Stream or Red Sea. There is no need to suppose that the Gulf Stream washed its northern shores, for the temperature would then be raised in excess of what is required, but its aid may be called in to account for the even warmer previous periods evidenced by the older growths of Gleichenia and cycads.

It does not necessarily follow that cold did not then exist towards the Pole. Disko is $20^{\circ}$ distant from it, and with an inclosed polar sea we should have a rapid lowering of temperature on the northern shores of the wide belt of land, and might have even a frozen ocean, perhaps as at present, with outlets on the side of Behring's Straits. The assumption that forests stretched to the Poles is not supported by the evidence.

The high temperature in these latitudes would be confined to the Atlantic; and that it was under the same laws as at present seems a reasonable supposition, since the American area even then maintained a relative cooiness on account probably of the return and cooler currents being sheared to the west by the rotation of the earth.

To recapitulate. I believe the evidence to be in favour of the eocene age ${ }^{-}$of the Arctic floras in question, and not miocene. I think that the temperature acquired by the plants-especially taking into consideration that their affinities with genera belonging to temperate regions is only inferred upon, in many cases, indistinct fragmentsmay have been over-estimated. There is no inherent impossibility indeed, that these extinct forms may not be the relics of a flora, like our present Arctic flora, specially adapted to bear a rigorous clime, and colour is lent to this by the abundance of the extinct McClintockia, about whose affinities we know nothing - a flora, perhaps, merely requiring the protecting cover of snow and sea-fog during winter. Finally, I believe that a comparatively slight change in the relative distribution of land and water, such as I have described, would alone account by itself for any fluctuations of temperature, of which we have any record preserved, in, at least, the tertiary rocks.

It does not come within the scope of the present subject, but it is worth consideration, whether wider channels still than those we now possess-some flowing from a more easterly point, so that our land might form the western coast of such a current-would not produce a glacial epoch, intensified by the absence of the Gulf Stream when there was no connecting isthmus (of which there is evidence in recent days) between the two Americas. The present distribution seems, at all events, one productive of more than average cold, as we become aware through the geological record, for the many and wide-existing channels conduct the Arctic waters south, and lower the general temperature of the ocean even to tho Tropics.

J. STARKiE Gardner

ON GAUSSIN'S WARNING REGARDING THE SLUGGISHNESS OF SHIP'S MAGNETISM 1

\section{Practical Rule and Caution}

I. A FTER steering for some time on westerly courses expect-

I. (a) Westerly error if you turn to the north;

I. (b) Or easterly error if you turn to the south.

2. After steering for some time on easterly courises expect-

2. (a) Easterly error if you turn to north;

2. (b) Or westerly error if you turn to the south.

The diagram representing case I $(a)$ illustrates the physical explanation, $N$ and $S$ representing the north and

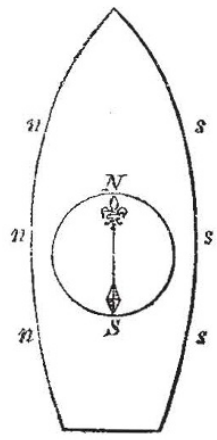

south points of the compass card (or true south and true north poles of its needles), and the small letters, $s, s, s$, true southern polarity, and $n, n, n$, true northern polarity, induced in the port and starboard ends of deck beams and port and starboard sides of ship while steering east, and remaining for some time after she has been turned to north.

In the "Admiralty Compass Manual" Gaussin's warning is given with reference to the direction of swinging, in correcting the compass by magnets according to Airy's

$x$ Being an abstract of a Cormmunication by Sir Wm. Thornson, F.R.S., to Section A of the British Ass aciation at its last meeting (Dublin). 